Kong. Res. J. 4(2): 133-135, 2017

ISSN 2349-2694

Kongunadu Arts and Science College, Coimbatore.

\title{
A NEW SPECIES OF CEROPEGIA L. (APOCYNACEAE) FROM SOUTHERN WESTERN GHATS OF INDIA
}

\author{
Karuppusamy, $S^{*}$. and V. Ravichandran \\ Department of Botany, Centre for Botanical Research, The Madura College (Autonomous), Madurai - 625011. \\ *E.mail: ksamytaxonomy@gmail.com
}

\begin{abstract}
Ceropegia paulsamii Karuppusamy et Ravichandran sp. nov. (Apocynaceae) is described and illustrated from Megamalai wildlife sanctuary in southern Western Ghats of Tamilnadu state, India. It is similar to Ceropegia decaisneana Wight but differs in sub-succulent fasciculate roots, flowers with short corolla lobes with middle constriction, outer corona trilobed, whitish, and basally caudate each coronal segment.
\end{abstract}

Keywords: Ceropegia paulsamii, Apocynaceae, western ghats, Megamalai wildlife sanctuary.

\section{INTRODUCTION}

Ceropegia L. (Apocynaceae, subfamily Asclepiadoideae) is a large, old world genus of about 200 species distributed largely in Africa, South Asia to part of Australia (Bruyns, 2003). In India, about 51 species have been described morphological basis and most of them are endemic to Western Ghats (Jagtap and Singh, 1999; Karthikeyan et al., 2009). Northern Western Ghats of Maharashtra region was well explored for genus Ceropegia by Prof. S.R. Yadav and his team. They have recognized many new species including $C$. anantii Yadav et al., C. anjanerica Malpure et al., C. bhatti Yadav et al. and $C$. mohanramii Yadav et al. in last decade. Southern Western Ghats are not well explored for this genus since many narrow endemic species are confined only hill peaks and grasslands in high altitudes. Bruyns (1997) have rightly noted that several nonsucculent species without tubers from Western Ghats seem to be both vegetatively and florally quite similar to species from West Africa and even to $C$. cumingiana from Australia. Some species are possessing peculiar floral structure and unusual coronal organization. These are possibly modern representatives of the most primitive form in the genus.

During a floristic survey in Theni district of Tamilnadu state, the authors collected a few interesting specimens of Ceropegia from Megamalai wildlife sanctuary of southern Western Ghats, that did not match with any other known Ceropegia species. After critical examination of these specimens, relevant literature search and consultation with Meve Ulrich, Dept. of Plant Systematics, Univ. of Bayreuth, Germany, it turned out to be a new species which is described and illustrated here.

\subsection{Ceropegia paulsamii Karuppusamy et} Ravichandran Sp. nov. (Fig. 1-2)

Ceropegia decaisneana Wight similis, rootis sub-succulentis fasciculatis, foliis ovato-oblongoellipticis nervis lateralibus 4-5 obliquis, calyxi lobi glabri, corolli lobi brevis $1.2 \mathrm{~cm}$ (nec $4 \mathrm{~cm}$ ) longis, corona exteriori trilobatis (nec bilobatis), albis, segmentis basis caudatis differt.

Type: India, Tamilnadu, Theni district, Megamalai wildlife sanctuary, ca $1300 \mathrm{~m}$ m.s.l. 18-12-2010, S. Karuppusamy and V. Ravichandran 1217 (holotype and isotypes: MH; paratypes: S. Karuppusamy and V. Ravichandran 1521, 1568, Herbarium of Department of Botany, The Madura College, Madurai, Tamilnadu)

\subsection{Etymology}

The new species named in the honor of Dr. S. Paulsamy, professor in department of Botany, Kongunadu Arts and Scinece College, Coimbatore for his valuable contribution in plant ecology and conservation in Nilgiri Biosphere Reserve for more than 25 years.

\subsection{Description}

Twining perennial herb. Root stock subsucculent, fasciculate, fibrous, ca. 5-8 cm long, 0.3 $\mathrm{mm}$ diameter, brownish, minutely hairy. Stem twining, ca $4 \mathrm{~m}$ long, branched, glabrous. Leaves opposite, shortly petiolate, ca $1-1.5 \mathrm{~cm}$ long; lamina ovate-elliptic or oblong elliptic, $5 \times 10-2-4 \mathrm{~cm}$, glabrous above, faint below, lateral nerves 4-5, oblique, margin entire, acuminate at apex. Inflorescence axillary, 3-5-flowered cymes, with peduncle ca 1-1.5 cm long, glabrous. Flowers bracteates; pedicel $0.8-1.2 \mathrm{~cm}$ long; bracts lanceolate, minute, ca $0.1 \mathrm{~mm}$ long, acute, glabrous. Calyx lobes 5, linear, 8-10 x $1.5 \mathrm{~mm}$, acuminate, glabrous. 


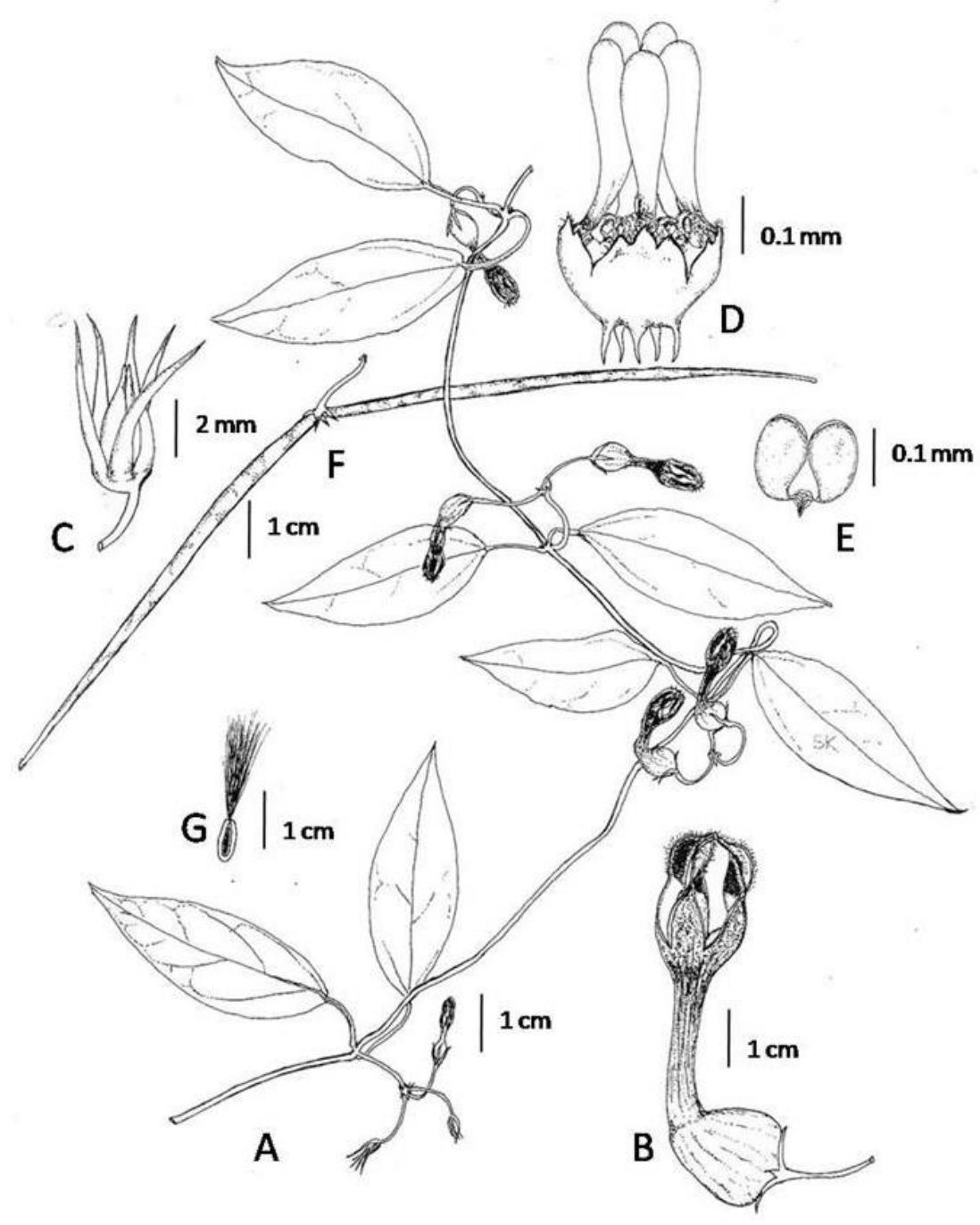

Fig. 1. Ceropegia paulsamii sp. nov. (A) twig, (B) flower, (C) calyx with young fruit, (D) corona lateral view, (E) pollinarium, (F) fruit, (G) seed.

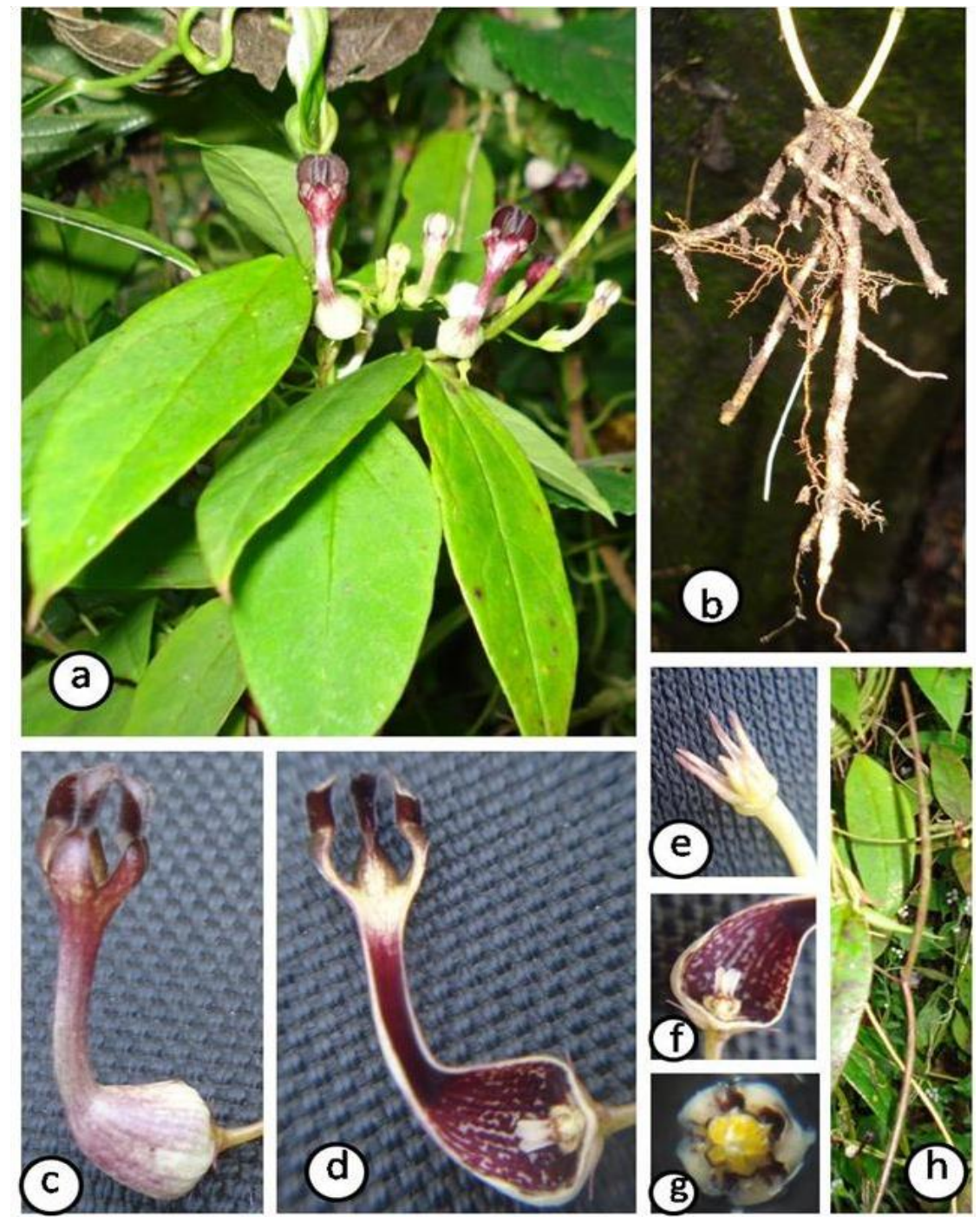

Fig. 2. Ceropegia paulsamii sp. nov. (a) habit, (b) subsucculent fasciculate root, (c) flower side view, (d) Flower longitudinal sectional view, (e) calyx with young fruit, (f) corona side view with inner side of corolla tube, (g) outer corona and staminal column top view, (h) mature fruit. 
Corolla tubular, $3.5-4.5 \mathrm{~cm}$ long, curved; base of tube inflated, globose, $1.2-1.9 \times 1.0-1.2 \mathrm{~cm}$, whitish with purple striations outside, deep purplish inside; corolla tube narrow cylindrical, slightly widened above, $1.5-2.2 \mathrm{~cm}$ long, $0.5 \mathrm{~cm}$ wide at base, $1.2 \mathrm{~cm}$ wide at mouth, mouth and tube molted dark purple above, deeply purplish inside, glabrous both sides; corolla lobes short, 0.8-1.2 cm, ellipticlanceolate, base broad, apex acute, folded back along the midrib, erect, margins hairy, constricted at middle, lobes joint to form a case at the apex, inside dark purple background. Corona sessile, creamy whitish, cupular, $0.4 \mathrm{~cm}$ diameter, outer corona trilobed, larger middle lobe and smaller side lobes, lobes triangular, margins hairy, each coronal segments basally caudate; inner corona linear, subulate, erect, $0.8-1.2 \mathrm{~cm}$ long, whitish, glabrous. Staminal column yellowish, $0.7 \mathrm{~mm}$ wide; stigma 0.2 mm wide; pollinarium $0.2 \times 0.3 \mathrm{~mm}$, pollen sacs erect with short caudicle. Pollen key shortly winged; corpuscle brown, rounded at apex. Follicle divergent, $7-15 \times 0.3 \mathrm{~cm}$, glabrous, terete, obtuse at apex. Seeds ovoid, flattened, $4 \times 2 \mathrm{~mm}$, dark brown, glabrous; coma $2.5 \mathrm{~cm}$ long, silvery white. Flowering and Fruiting: Throughout the year peak in September to January.

\subsection{Ecology and Distribution}

Ceropegia paulsamii Karupp. et Ravich. was found growing among bushes of shola borders at an altitude of $\pm 1400 \mathrm{~m}$ m.s.l. $9^{\circ} 36.430, \mathrm{~N}-77^{\circ} 18.50^{\prime}$ E., common in valleys and ravines of evergreen forests of Megamalai wildlife sanctuary. The plants are abundantly noticed in type locality about $50 \mathrm{~km}$ radius of the hill area from Iravangalaru to Vellimalai estates. The entire hill range is covered tea, coffee, cardamom and pepper cultivation. In between cultivation lands, the relict forest fringes and ravines are holding this new species. It perennates through subsucculent fibrous root stock and sprout onset of monsoon. Flowering year around but fruits set only seen in November to December.

\subsection{Similar species}

Ceropegia paulsamii is similar to Ceropegia decaisneana Wight but differs in its sub-succulent fasciculate roots, leaves ovate-oblong-elliptic with oblique 4-5, lateral nerves, glabrous calyx lobes, short corolla lobes $1.2 \mathrm{~cm}$ (vs $4 \mathrm{~cm}$ ), outer corona trilobed (vs bilobed), whitish, and coronal segments basally caudate (Table 1).

\section{ACKNOWLEDGEMENTS}

The authors are grateful to Dr. Meve Ulrich, Dept of Plant Systematics, Univ. of Bayreuth, Germany for his critical remarks over the taxon as a novelty.

Table 1. Differences in the Ceropegia decaisneana and Ceropegia paulsamii Karupp. et Ravi sp. nov.

$\begin{array}{ll}\text { Characters } & \text { C. decaisneana } \\ \text { Root } & \text { Tuberous } \\ \text { Leaves } & \begin{array}{l}\text { Linear-lanceolate or oblong-ovate, } \\ \text { lateral nerves 5-7-pairs. }\end{array} \\ \text { Calyx lobes } & \text { Ciliate } \\ \begin{array}{l}\text { Corolla } \\ \text { tube }\end{array} & \begin{array}{l}\text { Much inflated, broadly funnel- } \\ \text { shaped above, green with pale } \\ \text { purple spots all over }\end{array} \\ \text { Corona } & \begin{array}{l}\text { Orange, tipped with purple, outer } \\ \text { corona bifid or truncate, erect } \\ \text { process linear. }\end{array}\end{array}$

\section{REFERENCES}

Bruyns, P.V., (2003). Three new succulent species of Apocynaceae (Asclepiadaceae) from southern Africa. - Kew Bull. 58: 427-435.

Bryuns, P.V., (1997). A note on Ceropegia L. (Asclepiadaceae) of Silent Valley, Kerala, India. Rheedea 7: 107-114.
C. paulsamii sp. nov.

Subsucculent, fasciculate, $0.3 \mathrm{~mm}$ diameter.

Ovate-elliptic, oblong-elliptic, lateral nerves 4-5, oblique.

Glabrous

Ca. $2.5 \mathrm{~cm}$ long, inflated below, corolla lobes fused above to form a cage and constricted middle, tube molted with purple all over except inflated portion.

Whitish, outer corona trilobed, basally caudate each outer coronal segments.

Jagtap, A. and N.P. Singh, (1999). Asclepiadaceae and Periplocaceae. Fascicles of flora of India. Botanical Survey of India.

Karthikeyan, S., M. Sanjappa and S. Moorthy, (2009). Flowering plants of India, Dicotyledons Vol.I. (Acanthaceae - Avicenniaceae). Botanical Survey of India, Kokatta. 